\title{
REEL FuRY: White Fragility AND the BACKLASH Against BATHURST’s RoBIN $H O O D$
}

\author{
Lauryn Mayer \\ Washington \& Jefferson College
}

No remaking of the Robin Hood legend has garnered as much loathing as Otto Bathhurst's 2018 Robin Hood. While the majority of professional reviewers found elements to praise in the film, ${ }^{1}$ reviewers on Amazon, IMDB and Rotten Tomatoes unleashed their fury under the aegis of anonymity. ${ }^{2}$ Lamenting that they were robbed themselves, many reviewers claim to have walked out of the theater, and the reviews reveal a level of visceral disgust with the movie. On Amazon, "Sara B." advises: "Next time you go to the bathroom, look down into the bowl before you flush. Congratulations, you just created something more worthwhile than this film." ${ }^{3}$ Another Amazon reviewer describes the film as "a porta-john on a construction site."4 Multiple viewers make scatological comparisons or describe the film as "nauseating." 5 On IMDB, a user calling themselves "Dr. Graham Barkely, OBE" ${ }^{6}$ writes: "There's plenty more that makes it farcical that I could go into but I've just had lunch and I'd really like to keep it down if I could. So to sum up, my youngest son stepped in some fresh dog mess the other day. We had to throw his shoe away. Reminded me of this film."7

The majority of the reviewers tried to "throw the shoe away," giving the film the 1-star rating necessary to write the review, and then revoking the rating and invoking negative stars in the comments, despite the extra time and energy needed to do so. The film seems to take on the qualities of the abject, what must be literally thrown away. As Julia Kristeva describes the abject in The Powers of Horror:

A wound with blood and pus, or the sickly, acrid smell of sweat, of decay, does not signify death. In the presence of signified death - a flat encephalograph, for instance-I would understand, react, or accept. No, as in true theater, without

\footnotetext{
${ }^{1}$ For example, Owen Gleiberman calls the film "a diverting live-wire lark-one that, for my money, gets closer to the spirit of what Robin Hood is about than the logy 1991 Kevin Costner version or the dismal 2010 Russell Crowe version" ("Film Review: 'Robin Hood," Variety, Nov. 20, 2018). Geoffrey Macnab acknowledges its faults, but concludes that "[t]his is such an energetic affair that it hardly seems to matter when its aim is less than true" (Robin Hood Review," The Independent, Nov. 20, 2018).

${ }^{2}$ All reviewers will be referenced by the screen names used to leave their public reviews; links to the review (often left as a comment) and to the page are included.

${ }^{3}$ Sara B., “Deserves ZERO stars," April 26, 2019, Amazon.com comment / review of Robin Hood (2018).

${ }^{4}$ Amazon Customer, "So horribly pathetic I cant explain," March 8, 2019. Amazon.com comment / review of Robin Hood (2018).

${ }^{5}$ Kindle Customer, A bad Guy Ritchie impression featuring a woke Eggsy and AntiFa as heroes," February 6, 2019, Amazon.com comment / review of Robin Hood (2018); Diana, "Like a train wreck....so horrible but had to keep watching..." July 17, 2019, Amazon.com comment / review of Robin Hood (2018); Anonymous me, "Poorly written Anarcho-Communist Propaganda," May 26, 2020, Amazon.com comment / review of Robin Hood (2018).

${ }^{6}$ Obviously, no such person exists or has been knighted, but the pseudonym attempts to authorize the reviewer.

${ }^{7}$ Dr_Graham_Barkley_OBE “My son stepped in some dog mess,” Nov. 29, 2018, IMDB.com review of Robin $\underline{\text { Hood, }}$, directed by Otto Bathurst.
}

Lauryn Mayer, "Reel Fury: White Fragility and the Backlash Against Bathurst's Robin Hood." The Bulletin of the International Association for Robin Hood Studies 3 (2019): 10-22. 
makeup or masks, refuse and corpses show me what I permanently thrust aside in order to live. ${ }^{8}$

As Kristeva notes, the abject is not simply a site of disgust, but one that provokes a threat to life. We can see the echoes of the abject in what would otherwise look like ridiculous hyperbole in some of the reviews: from Amazon, "This is so horrible, I can't even describe the horror." ${ }^{9}$ On IMDB, a review by sebstallard is titled "Don't Wreck Your Life!" 10

What kind of threat to self does this film pose, to evoke such abject reviews? The majority of criticism centers on the film being too political or politically correct (to the reviewers) - an objection that begs the question, of course, as to which ideologies have been naturalized and are therefore not considered political. Robin DiAngelo's remarks on whiteness also apply to the naturalization of political ideologies (and the two are, of course, linked): "Whiteness rests on a foundational premise: the definition of whites as the norm or standard for human, and people of color as a deviation from that norm. Whiteness is not acknowledged by white people, and the white reference point is assumed to be universal and imposed on everyone." ${ }^{11}$ Much of the vitriol aimed at the film stems from the fact that it critiques these naturalized ideologies, a critique that (like discussions of race) provokes highly defensive behavior from those invested in these systems of domination. Interestingly, many of the reviews offer curatives to this abject deviation from whiteness: much of the advice given after these online rants is to watch either the Errol Flynn film The Adventures of Robin Hood (1938) or the Kevin Costner vehicle Robin Hood: Prince of Thieves (1991).

This advice is frankly puzzling, for the 2018 film has more in common with the films of 1938 and 1991 than these reviewers realize. Tropes associated with the tradition can be extrapolated to contemporary political flashpoints. For example, reviewers do not appear to object to redistribution of wealth; if such objections arose, potential viewers of the 2018 phenomenon would not have been directed towards the Errol Flynn film or the later Kevin Coster movie instead. Nor do viewers appear to take issue with the 2018 film's introduction of Marian as an early or prototypical Robin Hood, serving within the narrative as an inspiration for Egerton's character: Marian (played by Mary Elizabeth Mastrantonio) fights early and speaks aggressively in Prince of Thieves.

Reviews of the 2018 Robin Hood film may participate in a variation of a composition fallacy. Under this kind of faulty thinking, audiences conflate an attack on practices within an institution with an overt attack on the institution itself. For example, audiences perceive the film's depiction of corruption within the Church as an attack on the institution itself, or on Christianity more broadly. In the same manner, the portrayal of Muslims as victims of crusader abuses must somehow mean that all Christians are evil. Many of these reactionary interpretations (which absolve audiences of their own guilt) are on display in contemporary American race relations.

\footnotetext{
${ }^{8}$ Julia Kristeva, The Powers of Horror (New York: Columbia University Press, 1982), 12.

${ }^{9}$ Amazon Customer, "So horribly pathetic I cant explain," March 8, 2019, Amazon.com comment / review of Robin Hood (2018).

${ }^{10}$ sebstallard, "Don't wreck your life!!!," Aug. 4, 2019, IMDB.com review of Robin Hood, directed by Otto Bathurst.

${ }^{11}$ Robin DiAngelo, White Fragility (Boston: Beacon Press, 2018), 25. 
I thus wish to tease out two interconnected threads that constitute, for an audience such as the reviewers mentioned earlier, sufficient threats to motivate these feelings of disgust and horror in the 2018 Robin Hood film: the destruction of a reel racial hierarchy, and the threat to white supremacy posed by the movie's call for the overthrow of neoliberalism ${ }^{12}$ by collective revolution. ${ }^{13}$

Errol Flynn's Adventures of Robin Hood (1938) has long been interpreted by critics and audiences as a critique of contemporary Nazi Germany. ${ }^{14}$ Despite this history, however, the film now could be easily perceived by some viewers, particularly those with racist and xenophobic views, as satisfying modern white supremacy's whitewashing of history. The 1938 film's opening narrative describes the crusades as "fighting the infidels." Despite being set in 1191, one hundred twenty-five years after the Norman Conquest, the film makes a sharp division of the population of England between the decadent, predatory Norman invaders and the downtrodden but valiant Saxons, who are called the "true English." 15 Such framing makes the film prime material to be read as an anti-immigration allegory, much like the vile novel The Camp of the Saints (1973). The film also, of course, presents an all-white Middle Ages. ${ }^{16}$

Kevin Costner's Robin Hood: Prince of Thieves (1991), on the other hand, casts Morgan Freeman, a Black American actor, as Azeem; the film is the first big-screen remaking of the legend in which there is a Black co-star, or sidekick. ${ }^{17}$ Azeem's presence is a nod towards diversity, but for the most part, an empty gesture. Freeman's presence does nothing more than underscore longterm coded racial hierarchies in film ${ }^{18}$ while alleviating white guilt and playing on essentialist anti-

\footnotetext{
${ }^{12}$ For an excellent discussion of the mutually reinforcing relationship between neoliberalism (a political approach that favors free-market capitalism, privatization and reduced spending on social welfare programs) and forms of oppression such as racism and sexism, see Anne Sisson Runyon, Global Gender Politics (New York: Routledge, 2018).

${ }^{13}$ JanPattersonRN in her review calls out white assumptions of moral superiority: "Do you really think being white and raised in something nominally [but not in practice] Christian gives you protection from greed and power lust?" (“An old story writ new for our times," Jul. 6, 2019, Amazon.com comment / review of Robin Hood (2018)). Melvin predicts white fragility when he notes: "If you're white and racist you'll absolutely hate this movie" ("Best Robinhood ever!!!!,” Dec. 18, 2019, Amazon.com comment / review of Robin Hood (2018), directed by Otto Bathurst).

${ }^{14}$ Stephen Knight makes this point during his discussion of the Flynn vehicle in Robin Hood: A Mythic Biography, though Knight notes that though "an antifascist Robin is an appealing idea; yet some of the scenes most suggestive of Nazism, such as the scene in which Norman soldiers smash up shops" are also in the 1922 film, concluding that "antifascist interpretation may have more to do with the political context then and now than with any conscious plan on the part of the filmmakers" ("Robin Hood of Hollywood," in Robin Hood: A Mythic Biography [Ithaca: Cornell University Press, 2003], 150-210 at 158).

15 The Flynn film here echoes the nationalist sentiments popular in the nineteenth-century and brought fully into the popular Robin Hood tradition in Walter Scott's Ivanhoe (1819).

${ }_{16}$ Michael Curtiz and William Keighley, The Adventures of Robin Hood (Burbank: Warner Bros. Pictures, 1938).

${ }^{17}$ The BBC series Robin Hood (2006-2009) did see a Black actor, David Harewood, play Friar Tuck in its final season.

${ }^{18}$ A quick image search of biracial buddy movie posters provides a neat synecdoche of this hierarchy: when both actors are shown, the Black actor's face/body is almost invariably placed either behind or below that of the white actor.
}

Lauryn Mayer, "Reel Fury: White Fragility and the Backlash Against Bathurst's Robin Hood." The Bulletin of the International Association for Robin Hood Studies 3 (2019): 10-22. 
Muslim sentiment, ${ }^{19}$ to which Azeem is shown to be the sole exception. The film's establishment of Azeem's exceptionalism begins from the introductory shots, as the story opens in Jerusalem, focuses on a minaret, and zooms in on a muezzin reciting the adhan. The camera then immediately cuts to a dark and noisome dungeon where stereotypically stocky, scimitar wielding "Arabs" are administering amputations as punishment for thefts of bread, a montage meant to associate Islam with barbarity. Against this sinister backdrop, Robin of Locksley (although innocent of theft) offers himself up for amputation to save Peter, a weaker crusader, highlighting crusader virtue as opposed to Muslim ruthlessness. After a show of verbal valor ("This is English courage!" ), ${ }^{20}$ Locksley turns the tables on his captors, and as he escapes attempts to rescue fellow crusaders. Although Azeem, a Muslim, helped save Locksley by warning him of attackers behind him, Locksley initially does not agree to save him despite two separate please: Azeem first asks for freedom, because "I am under a sentence of death." ${ }^{21}$ His second plea is direct begging, playing on human compassion: "For pity's sake." Only when Azeem appeals to Locksley's sense of selfpreservation does Robin listen: "Set me free; I will show you a way out. If you do not, we are all dead men." 22 Azeem, for Locksley, is only valuable as an instrument; appeals to common humanity fall on deaf ears.

After helping Locksley escape, Azeem then insists on traveling with Locksley to England, in service to Locksley for saving his life, telling Locksley "I will stay with you until I have saved yours, that is my vow." ${ }^{, 23}$ Initially, Locksley high-mindedly refuses this service, even going to far as to try to ambush Azeem and ship him back East. When Locksley verbally releases Azeem from the debt, Azeem reminds him that "only Allah can do that," and declines his freedom. ${ }^{24}$ In doing so, the film naturalizes Azeem's wish to serve Locksley as one of free will, rather than overtly addressing an imbalanced power dynamic inherent in the concept of the life debt. With the specter of exploitation thus laid to rest by Azeem's own words, and the audience's guilt assuaged, Azeem can assume his place in the narrow racial narrative confines that have entrapped Black actors since The Birth of a Nation (1915): the loyal recipient of white paternalism; the "magical Negro"; or the brutish criminal. Ed Guerrero reminds us that Birth of a Nation demonstrated "how deadly serious the new medium [film], barely twenty years old, had become as a tool to create and shape public opinion and racial perceptions." 25 In these limited and thus inherently racist constructions, cinematic Black agency can only be portrayed as a threat to be contained. "Positive" black roles, in contrast, demonstrate what Patricia Turner denounces as the moviemaking community's "pernicious preference for docile, apolitical, nonthreatening black characters." ${ }^{26}$ For audiences in the first decades of the twenty-first century, Morgan Freeman's casting history has already mostly

\footnotetext{
${ }^{19}$ As discussed later, the only depiction of Muslims (other than Azeem) plays on the Orientalist stereotype of the "menacing Saracen." For a further discussion of this phenomenon in the Robin Hood corpus, see Kris Swank, "Black in Sherwood."

${ }^{20}$ Kevin Reynolds, Robin Hood: Prince of Thieves (Burbank: Warner Bros. Pictures, 1991)

${ }^{21}$ Reynolds, Robin Hood: Prince of Thieves.

${ }^{22}$ Reynolds, Robin Hood: Prince of Thieves.

${ }^{23}$ Reynolds, Robin Hood: Prince of Thieves.

${ }^{24}$ Reynolds, Robin Hood: Prince of Thieves.

${ }^{25}$ Ed Guerrero, Framing Blackness (Philadelphia: Temple University Press, 1993), 15.

${ }^{26}$ Patricia A. Turner, Ceramic Uncles and Celluloid Mammies (New York: Anchor Books, 1994), 218. 
coded into this latter nonthreatening category through his interchangeable characters in wellknown films, including Driving Miss Daisy (1989), The Shawshank Redemption (1994), and Bruce Almighty (2003). ${ }^{27}$

I assert that Freeman's filmography has already primed the twenty-first century audience to understand that 1991's Prince of Thieves will not be a threat to white supremacy; indeed, it might even play into a nostalgia for Black characters who are forced to explicitly address their own outsider minority status. When Locksley questions why Azeem is "walking at the back of [him]" Azeem responds "In your country, am I not the infidel? It seems safer to appear as your slave, rather than your equal." 28 The film sets up an unequal "buddy" relationship, and as Guerrero notes:

It seems that with the biracial buddy formula Hollywood put the black filmic presence in the protective custody, so to speak, of a white lead or co-star and therefore in continuity with white sensibilities and expectations of what black, essentially, should be. ${ }^{29}$

Locksley responds by essentializing Azeem's point about perspective: "For an infidel, you have uncommon clarity of thinking." ${ }^{30}$ From this point on, literally and metaphorically, Azeem walks behind Robin: he helps Robin train the younger fighters, fights for Robin, and indulges in some caustic comments about supposed English superiority, but his role is one that is "legible" to a white audience: either the wisecracking Black sidekick or the wiser, older Black helper. Locksley is the dominant figure throughout the film, from organizing the fighting men to designing the various traps and stratagems that help them steal from the Sheriff of Nottingham. Locksley does chide the rest of the outlaws of Sherwood for their reluctance to include Azeem in their comradery: when they refuse to share alcoholic drinks with Azeem, the exclusion is pitched in racial overtones. The one-off gesture is a token attempt at inclusion, meant to highlight Locksley's obligations to Azeem as a protector and Azeem's dependence upon Locksley as champion. This is a common move that Turner sees in other films supposedly addressing racism that "exaggerate the role whites have played in fighting racial hostility." 31

Moreover, the film is quick to point out Azeem's weaknesses and re-inscribe them racially and religiously. From early in their time in England Locksley sees Azeem's devotions and prayers as hindering Locksley's heroism, for example during Locksley's attempt to rescue a poaching urchin from the Sheriff of Nottingham's thugs (including Guy of Gisborne). The camera shift from Locksley, desperately using any weapon at hand against six other men and their hunting dogs, to Azeem placidly continuing his prayers. After Locksley chases the men off, he accuses Azeem of neglecting his vows, and Azeem calmly replies that "I fulfill my vows when I choose to" as Locksley bitterly replies, "Which does not include prayer time, meal time, or any time I'm outnumbered six to one." Though the scene ends comedically, when Azeem dismisses Robin's

\footnotetext{
${ }^{27}$ While Freeman has played a variety of roles, the ones that have garnered the most acclaim are those in which he plays a character that is "legible" to white audiences.

${ }_{28}^{2}$ Reynolds, Robin Hood, Prince of Thieves.

${ }^{29}$ Guerrero, Framing Blackness, 128.

${ }^{30}$ Reynolds, Robin Hood, Prince of Thieves.

${ }^{31}$ Turner, Ceramic Uncles and Celluloid Mammies, 168.
} 
objections by pointing out, "You whine like a mule. You are still alive,"32 the moment sets up Azeem as violating his role as helper-and thus, as a Black man, he becomes dangerous and requires punishment. Later, when Azeem thinks he hears ghosts in Sherwood Forest as the pair enter looking for the outlaw band, Locksley quickly points to wind chimes that he, as a native, must surely expect: "You're scared easily, my painted Moor." "33 Two parts of this response need to be stressed: first, the phrase "painted Moor" rather than "Azeem" is a dog whistle for the audience to view Azeem's fear as a racial failing. ${ }^{34}$ Second, Locksley's use of the possessive adjective, in a moment when the two are alone, plays overtly into Azeem's statement that he wishes to be perceived as Locksley's slave. This "doubling" of Azeem, simultaneously subordinated to Locksley in the racial hierarchy while purportedly "free" from literal enslavement, is designed to placate a white audience unwilling to address the brutal reality of systemic racism. For them, the end of literal slavery means that Black individuals have equal freedom with white ones - and that racism is an individual character flaw rather than a continually reproduced structure of domination. As DiAngelo notes:

Racism-like sexism and other forms of oppression - occurs when a racial group's prejudice is backed by legal authority and institutional control. This authority and control transforms individual prejudices into a far-reaching system that not longer depends on the good intentions of individual actors; it becomes the default of the society and is reproduced automatically. ${ }^{35}$

This blindness to systemic racism is a form of aggression and persecution of its own. Ijeoma Oluo discusses precisely this topic when talking about racism and police brutality: "In this individualist nation we like to believe that systemic racism doesn't exist. We like to believe that if there are racist cops, they are individual bad eggs acting on their own. And with this belief we are forced to prove that each individual encounter with the police is definitely racist or it is tossed out completely as mere coincidence." 36

By contrast to the films that reviewers recommend as a curative to the 2018 film, Bathurst's reworking of the legend presents an astounding lack of agency given to Robin of Loxley. ${ }^{37}$ The film opens, indeed, with a stealthy and clever thief who is robbing the rich to give to the poor: but the thief is Marian stealing a horse from Robin. When Robin catches her, she turns his arrogant attempts at seduction into a denunciation of the idle aristocracy. Robin releases Marian, and gives her the horse, but only on condition that she give him her name. This is a disturbing scene to watch, since he pins Marian to the wall, all the while giving her a harasser's smirk; ${ }^{38}$ the threat of rape is evident, as is Robin's economic privilege.

Robin's presence seems to corrupt Marian: after their meeting, the film provides a montage of their lovemaking in the manor, a space that is physically and symbolically higher and further

\footnotetext{
${ }^{32}$ Reynolds, Robin Hood, Prince of Thieves.

${ }^{33}$ Reynolds, Robin Hood, Prince of Thieves.

${ }^{34}$ Locksley also refers to Azeem as a "painted old hound," while trying to learn the name of the woman for whose love Azeem was sentenced to death.

${ }^{35}$ DiAngelo, White Fragility, 21.

${ }^{36}$ Ijeoma Oluo, So You Want to Talk About Race (New York: Seal Press, 2018), 89.

${ }^{37}$ Otto Bathurst, Robin Hood (Santa Monica: Lionsgate Pictures, 2018).

${ }^{38}$ Bathurst, Robin Hood. 
away from the town and the mines. Marian seems to have forgotten her commitment to her people; far from the daring thief of her first appearance, the film only shows her and Robin embracing in soft focus as the voiceover tells us that "seasons passed, and their romance blossomed. They were young, in love and that was all that mattered" (emphasis mine). ${ }^{39}$ Their idyll ends abruptly when Robin is drafted to fight in the crusades, a startling departure from the voluntary service he provides in Prince of Thieves and Ridley Scott's 2010 Robin Hood, the two blockbuster films most recently preceding the 2018 movie. Indeed, military service seems to be key to making Robin something more than a smirking harasser: the film jumps forward in time, and the audience next see Robin and his squad of crusaders ${ }^{40}$ fighting a losing battle against the technologically-superior and strategically more brilliant Muslims. When one of the crusaders is captured and hung up as bait for the rest, the film does a savage takedown of the classic "daring rescue" trope of action movies. Robin insists trying for the rescue, and not only fails, but is responsible for the deaths of dozens of the crusaders as they follow him into a trap. The Muslim squad is led by a masked man the audience later learns is Yahya, a warrior of incredible speed, strength, and dexterity. Yahya defeats Robin by throttling him; as Robin loses consciousness, he is saved by another crusader cutting Yahya's hand off amidst the bombardment of the city by the crusaders' late-arriving backup forces. The defeated Muslims are put into chains, and abused in a fashion visually reminiscent of tortures at Abu Ghraib. ${ }^{41}$ Robin rebels against the execution of Yahya's son, but cannot stop it: ${ }^{42}$ instead, he is shot himself, threatened with execution (saved only by his class privilege), and dumped on a hospital ship back to England. While his compassion for the Muslim captives puts him on the moral high ground, he lacks the power to enact justice and save the captives. ${ }^{43}$

The first shot of the hospital ship focuses on the recumbent and unconscious Robin, who is dreaming of Marian, before panning down through a grate to see Yahya sitting upright in the bilge, alert and waiting. ${ }^{44}$ Notably, although the shot is meant to be reminiscent of the horrific slave ships of the Middle Passage, here it is Yahya who has the power and agency, as he has chosen - without Robin's knowledge - to board the ship and shadow Robin home. This shot of Robin unconscious and Yahya in control of his circumstances echoes the earlier scene where Robin was throttled into unconsciousness by Yahya, and trains the viewer to read Robin as passive in comparison to Yahya.

\footnotetext{
${ }^{39}$ Bathurst, Robin Hood.

${ }^{40}$ While the crusader's costumes summon up images of SWAT teams and urban combat attire, the film is careful to frame this as a medieval crusade. The "draft notice" handed to Robin uses the medieval technique of rubrication to highlight "The Third Crusade" in vivid red; Robin's memory sequence on the hospital ship pulls out all the tropes associated with the crusade: medieval armor and white banners with the red cross on them.

${ }^{41}$ As Robin walks through the crusader encampment, the camera follows his eyes as crusaders force their chained Muslim prisoners to kneed ("On your knees, you pig"), assault them, and force their heads onto a block in a fashion that seems to deliberately not only the disturbing images released from Abu Ghraib, but also the opening scene of Robin Hood: Prince of Thieves (1991) discussed above.

${ }^{42}$ He does manage to free Yahya and others, which allows Yahya to follow him back to England.

${ }^{43} \mathrm{We}$ 'll see this same combination of morality and helplessness later in the film, where the community as a whole is being beaten in an attempt to discover the identity of The Hood; Robin gives himself up to the Sheriff's thugs, but while this temporarily staves off that particular round of violence, it does nothing to change the system of violence and exploitation regularly unleashed upon the community.

${ }^{44}$ Bathurst, Robin Hood.
}

Lauryn Mayer, "Reel Fury: White Fragility and the Backlash Against Bathurst's Robin Hood." The Bulletin of the International Association for Robin Hood Studies 3 (2019): 10-22. 
Robin returns to England to find his home a ghastly looted ruin, the town turned into a Victorian industrial dystopia, and Marian embracing another man. This last sight causes him to double over, retching and weeping, and it is in this moment of Robin's abjection that Yahya bursts on the scene with dazzling energy. ${ }^{45}$ The scene is worth remembering in full to show the startling contrast between the helpless and the determined Yahya. Robin looks up to see Yahya standing over him. He attempts to escape, but Yahya literally bars his way with one hand and stops his selfpitying plaint of "You should have killed me; this must be hell" 46 by angrily lashing back: "You want to know what hell is? I lost my hand in this war. My people were in chains. My land was pillaged. And my son was murdered." ${ }^{47} \mathrm{He}$ then reveals that he has chosen Robin as his instrument to help fight a new war, one which frames them as equals in a struggle against the predatory rich who have embroiled both their nations in war for fiscal gain. Yahya concludes his recruitment speech with an imperative: "Follow me, English," 48 in a striking verbal echo of Azeem's nickname for Locksley, and possibly deliberate physical reversal of Azeem's walking behind Locksley in Prince of Thieves.

From the beginning of the relationship, Yahya is dominant, a startling departure from the norm in film, especially since this pattern continues throughout the movie. As Guerrero notes, commenting on Black representation in the wake of Birth of a Nation:

in almost every instance, the representation of black people on the commercial screen has amounted to one grand multifaceted illusion. For blacks have been subordinated, marginalized, positioned, and devalued in every possible manner to glorify and relentlessly hold in place the white-dominated symbolic order and racial hierarchy of American society. ${ }^{49}$

When IMDB reviewers make comments dismissing the film as "liberal propaganda about social justice and other garbage" concluding "this was probably filmed by Obama," 50 and another reviewer on Amazon frames a rant about how the film has stolen from white history and culture in whataboutism, ${ }^{51}$ it is not hard to see that behind the fury is a sense of what Michael Kimmel terms "aggrieved entitlement," a zero-sum mentality where any gain by a non-dominant group must mean a corresponding loss inflicted on the dominant group. ${ }^{52}$

\footnotetext{
${ }^{45}$ Bathurst, Robin Hood.

${ }^{46}$ Bathurst, Robin Hood.

${ }^{47}$ Bathurst, Robin Hood.

${ }^{48}$ Bathurst, Robin Hood.

${ }^{49}$ Guerrero, Framing Blackness, 4 and 5.

50 aypostnet, "Left the theater after 5 minutes and a good meal," Nov. 29, 2018, IMDB.com review of $\underline{\text { Robin Hood, }}$ directed by Otto Bathurst.

${ }^{51}$ Dracula, "Horrible," Mar. 23, 2019, Amazon.com comment / review of Robin Hood (2018, directed by Otto Bathurst. The review's whataboutism is worth examining at length: "Another garbage re-do of a classic. Guess what. White people do exist, and we do have a history, and we do have tales that originated from our own cultures. It doesnt meant we're the only ones - but stop trying to put an idealistic philanthropic agenda into every piece of entertainment that exists. Learn some real history. Only $2 \%$ of whites have slave owners in their heritage. Look up the barbary piracy wars - the arabs enslaved MILLIONS of black north Africans and whites until the US invented a navy and worked with the British to end the piracy. Love your fellow man and stop trying to rewrite tales. Bring black people into the stories, thats fine, but stop pushing a globaist agenda by destroying these tales."

${ }^{52}$ Michael Kimmel, Angry White Men (New York: Nation Books, 2017), 24.
} 
Yahya's competence is thus seen as an attack on Robin, and through Robin, whiteness. Yahya is the one who comes up with the plan to steal from the Sheriff of Nottingham: "Nottingham is the bank and the beating heart of the crusades, and I want to put a knife through it,"53 a move that would literally defund the crusades. He forges Robin's new identity as a duality, designed to be in total service to their new cause: "By night you'll be hitting the sheriff's couriers, toll takers, tax collectors... by day, you'll be playing Lord Loxley, drinking and dining with some of the most obnoxious people on earth." Note here that this forging of Robin's new identity means that Yahya now has complete military control over every hour of Robin's life, a point which the film makes clear: when Robin complains about a task, saying "It's my day off," Yayha snaps back, "You have no days off, English." 54 Yahya bars Robin from seeing Marian again, swats a bottle of spirits from Robin's hand when he attempts to drown his sorrows in alcohol, and physically shakes Robin to make his point about sticking to the plan. To demonstrate to Robin, and the audience, that Robin is indeed not yet at Yayha's level of strength and speed, Yahya bests Robin, armed only with a staff and missing a hand. The training montage includes a grueling session where Yahya looms over Robin while barking out orders. The two are not training together: Yahya acts like a stereotypical Marine drill sergeant, breaking down Robin to turn him into a fighting instrument. In a striking visual reversal of slave/master images during these training sessions, it is Robin — not the Black man - who is weighted down with chains and dragging them along the ground. The camera focuses and the montage pauses on several moments when the audience sees a switch in the plantation trope of white leisure and Black labor. The racial implications are clear: while Robin sweats with exertion, the camera pans to Yahya sitting down and eating.

Although reviews from Empire, Variety, The New York Times, and others downplay Yahya's position as one of "sidekick," 55 the movie drives home the message time and time again that Robin is simply a body performing Yahya's will. Beyond the overt dialog when Yahya recruits and trains Robin, Yahya's competence is highlighted through his competence in unexpected circumstances. For example, at one point in the film Yahya allows himself to be captured to save Robin and Marian and frees himself using found tools and his own fighting ability. After a defiant speech to the Sheriff of Nottingham sees him imprisoned, Yahya is brought food in a crockery pot. Using his head, he smashes the pot and hides one of the shards in his teeth. When a guard approaches to beat him, Yahya swings his head around, wounds the guard in the head with the

\footnotetext{
${ }^{53}$ Bathurst, Robin Hood.

${ }^{54}$ This double identity instantly invokes the playboy/crime fighter characters of Batman and Zorro, with one important distinction: whereas the two are exemplars of self-forged identities, Robin literally has no voice in creating his own role.

${ }^{55}$ It's interesting to note how the professional reviews insist, in the face of the arc of the entire film, on classing Yahya as a secondary character. Two examples will show the pattern. Gleiberman spends one sentence of his review on Foxx's character, and classifies Yahya's and Robin's relationship as "a mutually beneficial bond" (Gleiberman, "Film Review: 'Robin Hood"). Dan Jollin writes that "Foxx is criminally wasted in a sidekick role that requires little more of him than the aforementioned exposition and a bit of training-montage shouting" "Robin Hood Review," Empire Online, Nov. 19, 2018); Jollin also finds it ludicrous that longtime Moorish commander would know anything about English politics: "And a Moor who's somehow familiar with the inner workings of the English political and economic system despite just arriving in the country only adds to the preposterousness of it all." 
shard, and then throttles him with his own chain. By contrast, Robin's own two attempts at leadership end poorly, and he requires rescue by Yahya. ${ }^{56}$

Even Robin's words are not his own: "Too slow!" yells Yahya as Robin fails in his training; "Too slow!" Robin then taunts the first toll guard who tries to attack him. Robin mirror's Yahya's phrasing in complex situations as well: Yahya declares that "We pull the tail and see who bites" when outlining his strategy to infiltrate the inner circles of Nottingham power. During an exchange between Robin and Yahya, Robin declares he wants to "go big" and attack the treasury directly; his justification, when Yayha observes the difficulty of the task, is to parrot Yahya's own words: "We pull the tail and see who bites." 57

Yahya is the will and Robin is the instrument, well-summarized in one of Yahya's training instructions: "You must make your hand a quiver." 58 This phenomenon is what infuriates viewers who are much more comfortable with Black bodies acting as the instruments of white will. This also illuminates what would otherwise be a puzzling paradox: despite Yahya's evident leadership, ${ }^{59}$ the same adjective, "useless," is echoed over and over again in reviews. Moreover, the criticisms of the character (Yahya, but usually called Little John) are closely linked to the actor: "Jamie fox's [sic] character is useless" is a commonly replicated phrase, ${ }^{60}$ while other reviews use Yahya, as played by Foxx, representative of their criticism of the film, saying "Characters, specially Jamie Foxx made no sense to me." 61 Even well-written and thoughtful reviews miss the point the film is making: Foxx "achieves the impossible at making a crucial character such as Little John out of place and serving little point to the story." 62 Yahya is far from "useless" in the film. But in a culture of systemic racism that demands certain roles and behaviors from people of color, and will react with fear and rage if those demands are challenged, he is useless because he does

\footnotetext{
${ }^{56}$ Robin's plan to hit the treasury stumbles when he realizes that the entire cart carrying the treasure is going to be lowered into the vault itself, making escape next to impossible. He then is discovered hiding under the cart by a guard, and is seriously wounded trying to escape from an increasing number of attackers. He is only saved when Yahya manages to drive a cart under the battlements Robin in running on, allowing him to jump and be carried away, a scene once again showing his passivity. We see this again when Robin's revealing of himself to save the townspeople only offers them a temporary respite, and he must be rescued from certain death by Yahya, who has disguised himself as one of Nottingham's thugs.

${ }^{57}$ Bathurst, Robin Hood. Notably, the entire interchange here reads like a child wanting and begging to ride a bicycle without training wheels.

${ }^{58}$ Bathurst, Robin Hood.

${ }^{59}$ As one reviewer complained, "The Moor (Jamie Fox [sic] was the better fighter, planner and most benevolent character in the movie and Robinhood [sic] seemed to be the second banana. The Moor had to teach Robin of Locksley [sic] how to fight and tell him what to do in almost every situation, might as well titled the movie after him." (Super Shopper, review of Robin Hood). Note the emphasis on Foxx's "otherness" here. Another gave the film one star because "the good guy is not a hero and is lead [sic] by his second head." (Dad's Review, review of Robin Hood ). In this reviewer's view, "good guys" implies whiteness. Patricia Turner notes the ways "Disney studios ensured that generations of American children would shudder with apprehension when darkness appeared and utter sighs of relief at lightness." (Ceramic Uncles and Celluloid Mammies, 107)

${ }^{60}$ mahmoudelkotb-512-910350, “An utter disastet," Biv, 29, 2018, IMDB.com review of Robin Hood, directed by Otto Bathurst. The wording is identical in both reviews, and echoed in too many others to list.

${ }^{61}$ Honest Reviewer, "Very Disappointing!," Feb. 26, 2019, Amazon.com comment / review of Robin Hood (2018), Robin Hood (2018), directed by Otto Bathurst.

${ }^{62}$ TheLittleSongbird, "The un-entertaining and un-thrilling story of Robin Hood," Nov. 24, 2018, IMDB.com review of Robin Hood, directed by Otto Bathurst.
}

Lauryn Mayer, "Reel Fury: White Fragility and the Backlash Against Bathurst's Robin Hood." The Bulletin of the International Association for Robin Hood Studies 3 (2019): 10-22. 
not fit the passive Black helper / sidekick model to a white hero. Viewers cannot "use" John to reinscribe racist hierarchies: thus, he is useless.

Unlike more conservative Robin Hoods that critique figures within a system while championing the system itself, ${ }^{63}$ Bathhurst's Robin Hood (a white man driven by a Black man's ideology) demands the overthrow of a neoliberalism that pits races and religions against each other to distract them from its ravages. As Yahya explains to the naïve Robin: "This war, all wars, and everything happening here [the exploitation of the commoners], it's as old as time. Rich men getting richer. Men of power, taking more power from the blood of innocents. Yours, mine, and my son's." ${ }^{64}$ By framing himself and Robin as equal victims of economic and political oppression, Yahya threatens what W.E.B. Dubois terms the "public and psychological wage" of whiteness. As Jonathan Metzl describes it, “'Whiteness' thereby provided 'compensation' for citizens otherwise exploited by the organization of capitalism — while at the same time preventing working-class white Southerners from forming a common cause with working-class black populations in their shared suffering at the bottom of the social ladder." 65 To think about a shared cause means to erase the distinction between white and Black, and in a structure of systemic racism, whites view the loss of their place at the top of the racial hierarchy as a threat to self, one which must be violently "thrown away." By systematically downgrading the film, the reviewers are trying to throw away the message they fear and despise.

\footnotetext{
${ }^{63}$ In Robin Hood: Prince of Thieves, both Locksley and his father are loyal subjects of Richard the Lionhearted. The casting and costuming of the villains in Prince of Thieves deploys a Chaucerian tactic of displaying moral corruption through individual physical appearances (Chaucer's Summoner, for instances, bears the marks of moral infection on his pustulent visage). Thus the corrupt civic judicial system is indicated in the decayed teeth of Guy of Gisborne; the money-stuffed Church is reflected in the bloated face of the Bishop; literal moral blindness in Mortianna; the corruption of office in the black-clad and often slouched figure of the Sheriff of Nottingham.

${ }^{64}$ Many of the reviewers complain about the film as borrowing heavily from such films as The Matrix, $V$ for Vendetta, and The Hunger Games. However, the point of these borrowings is precisely to show the omnipresent ravages of economic inequality and the pervasive threat of oppressive regimes.

${ }^{65}$ Jonathan Metlzl, Dying of Whiteness (New York: Basic Books, 2019), 17. 


\section{BIBLIOGRAPHY}

Bathurst, Otto, dir. Robin Hood. Summit Entertainment and Lionsgate, 2018.

Curtiz, Michael and William Keighley, dirs. The Adventures of Robin Hood. Warner Bros., 1938. DiAngelo, Robin. White Fragility: Why It's So Hard for White People to Talk About Racism. Boston: Beacon Press, 2018.

Gleiberman, Owen. "Film Review: 'Robin Hood," review of Robin Hood (2018), directed by Otto Bathurst. Variety, November 20, 2018. https://variety.com/2018/film/reviews/robinhood-review-taron-egerton-jamie-foxx-1203033148/

Guerrerro, Ed. Framing Blackness: The African American Image in Film. Philadelphia: Temple University Press, 1993.

Jollin, Dan. "Robin Hood Review," review of Robin Hood (2018), directed by Otto Bathurst. Empire, November 19, 2018. https://www.empireonline.com/movies/reviews/robin-hood-4review/

Kimmel, Michael. Angry White Men: American Masculinity at the End of an Era. New York: Nation Books, 2017.

Kristeva, Julia. The Powers of Horror: An Essay on Abjection. Trans. Leon S. Roudiez. New York: Columbia University Press, 1982.

MacNab, Geoffrey. "Robin Hood Review: 'This Rip-Roaring Version is for the Superhero Era,"' review of Robin Hood (2018), directed by Otto Bathurst. The Independent, November 20, 2018. https://www.independent.co.uk/arts-entertainment/films/reviews/robin-hoodreview-film-movie-taron-egerton-otto-bathurst-cast-a8642931.html

Metzl, Jonathan M. Dying of Whiteness: How the Politics of Racial Resentment is Killing America's Heartland. New York: Basic Books, 2019.

Oluo, Ijeoma. So You Want to Talk About Race. New York: Seal Press, 2018.

Reynolds, Kevin, dir. Robin Hood, Prince of Thieves. Morgan Creek and Warner Bros., 1991.

Swank, Kris. "Black in Sherwood: Race and Ethnicity in Robin Hood TV and Film". https://www.academia.edu/11363597/Black_in_Sherwood_Race_and_Ethnicity_in_Robi n_Hood_TV and Film. Accessed July 6, 2020.

Turner, Patricia A. Ceramic Uncles and Celluloid Mammies: Black Images and Their Influence on Culture. New York: Anchor Books, 1994.

\section{VIEWER REVIEWS: AMAZON.COM}

Amazon Customer, March 8, 2019. "So horribly pathetic I cant explain." Amazon.com comment / review of Robin Hood (2018), directed by Otto Bathurst.

Anonymous Me, May 26, 2020. "Poorly written Anarcho-Communist Propaganda."

Amazon.com comment / review of Robin Hood (2018), Robin Hood (2018), directed by Otto Bathurst.

Diana, July 17, 2019. "Like a train wreck....so horrible but had to keep watching..." Amazon.com comment / review of Robin Hood (2018), Robin Hood (2018), directed by Otto Bathurst. 
Dracula, March 23, 2019. "Horrible." Amazon.com comment / review of Robin Hood (2018), Robin Hood (2018), directed by Otto Bathurst.

Honest Reviewer, February 26, 2019. "Very Disappointing!" Amazon.com comment / review of Robin Hood (2018), Robin Hood (2018), directed by Otto Bathurst.

JanPattersonRN, July 6, 2019. "An old story writ new for our times." Amazon.com comment / review of Robin Hood (2018), Robin Hood (2018), directed by Otto Bathurst.

Kindle Customer, February 6, 2019. "A bad Guy Ritchie impression featuring a woke Eggsy and AntiFa as heroes." Amazon.com comment / review of Robin Hood (2018), Robin Hood (2018), directed by Otto Bathurst.

Melvin, December 18, 2019. "Best Robinhood ever!!!!” Amazon.com comment / review of Robin Hood (2018), directed by Otto Bathurst.

Sara B., April 26, 2019. "Deserves ZERO stars." Amazon.com comment / review of Robin Hood (2018), directed by Otto Bathurst.

\section{VIEWER REVIEWS: IMDB.COM}

aypostnet, November 29, 2018. "Left the theater after 5 minutes and a good meal." IMDB.com review of Robin Hood, directed by Otto Bathurst.

Dr_Graham_Barkley_OBE, January 28, 2019. "My son stepped in some dog mess." IMDB.com review of Robin Hood, directed by Otto Bathurst.

mahmoudelkotb-512-910350, November 21, 2018. "An utter disastet." IMDB.com review of Robin Hood, directed by Otto Bathurst.

sebstallard. August 4, 2019. “Don't wreck your life!!!" IMDB.com review of Robin Hood, directed by Otto Bathurst.

TheLittleSongbird. November 24, 2018. "The un-entertaining and un-thrilling story of Robin Hood." IMDB.com review of Robin Hood, directed by Otto Bathurst. 